\title{
Estrone Sulfate: Production Rate and Metabolism in Man
}

\author{
HeNRy J. Ruder, Lynn Loriaux, and M. B. LipsetT \\ From the Reproduction Research Branch, National Institute of Child Health \\ and Human Development, Bethesda, Maryland 20014
}

A B S T R A C T Since estrone sulfate $\left(E_{1} S\right)$ is present at high concentration in plasma, we have examined the parameters of the plasma estrone, estradiol, $\mathrm{E}_{1} \mathrm{~S}$ system. The metabolic clearance rate of $E_{1} S$ was 157 liter/day (range 70-292) in men and women. Estimated plasma production rates of $\mathrm{E}_{1} \mathrm{~S}$ were ( $\mu$ grams per day): men, 77 ; women, early follicular phase, 95 ; women, early luteal phase, 182. The conversion of plasma estrone and estradiol to $\mathrm{E}_{1} \mathrm{~S}$ was measured and from these data and the metabolic clearance rates of the estrogens, the transfer factors were $\rho^{\mathrm{m}_{1} \mathrm{~m}_{1}^{\mathrm{S}}}=0.54$ and $\rho^{\mathrm{m}_{2} \mathrm{~m}_{1}^{\mathrm{g}}}=0.65$. Using average production rates, all plasma $E_{1} S$ could be shown to be derived from plasma estrone and estradiol.

The conversion of plasma $E_{1} S$ to plasma estrone and estradiol was studied. The calculated transfer factors were: $\rho^{\mathrm{F}_{1} \mathrm{sE}_{1}}=0.21, \quad \rho^{\mathrm{F}_{1} \mathbf{S E}_{2}}=0.014$. Essentially, similar data were obtained when $E_{1} S$ was given by mouth to two subjects.

We conclude: (a) $\mathrm{E}_{1} \mathrm{~S}$ is a major circulating plasma estrogen and has a long plasma half-life; $(b)$ the large contributions of estrone and estradiol to plasma $\mathrm{E}_{1} \mathrm{~S}$ are more than sufficient to account for all the circulating plasma $E_{1} S$.

\section{INTRODUCTION}

Estrone-3-sulfate $\left(E_{1} S\right)^{1}$ is the major component of the conjugated equine estrogens and of other estrogenic preparations and has been used for over 30 years for treatment of the postmenopausal woman. Although estrone sulfate has been identified in human urine, little is known of its blood levels and metabolism. Twombly and Levitz showed that estrone sulfate had a long half-

\footnotetext{
Received for publication 24 September 1971 and in revised form 22 November 1971.

${ }^{1}$ Abbreviations used in this paper: DCC, dicyclohexylcarbodiimide; DHS, dehydroeipandrosterone sulfate; DMF, dimethyl formamide; $E_{1}$, estone ; $E_{2}$, estradiol ; $E_{1} S$, estrone-3sulfate; MCR, metabolic clearance rate; $\mathrm{RBC}$, red blood cells; TLC, thin-layer chromatography.
}

life in blood (1), and Purdy, Engel, and Oncley (2) found that it was the major plasma metabolite of estradiol and that it was present in high concentration in pregnancy. During previous studies of estrogen metabolism we had postulated (3) that there was another plasma estrogen compartment in equilibrium with plasma estrone $\left(E_{1}\right)$ and estradiol $\left(E_{2}\right)$. Since it seemed probable that this compartment was estrone sulfate, we initiated studies of the origin, rates of metabolism, blood levels, and conversions of estrone sulfate. These studies have confirmed the finding that $\mathrm{E}_{1} \mathrm{~S}$ is an important plasma metabolite of estradiol and have defined the production rate of $E_{1} S$ and its interconversions with estrone and estradiol.

\section{METHODS}

Materials. Estrone- $6,-7-{ }^{3} \mathrm{H}$, estradiol- $17 \beta-6,7-{ }^{8} \mathrm{H}$, estrone$3-\mathrm{NH}_{4}$-sulfate- $6,-7-{ }^{8} \mathrm{~S}(40 \mathrm{Ci} / \mathrm{mmole})$, and estrone- $4-{ }^{14} \mathrm{C}$ and estradiol-17 $\beta-4-{ }^{14} \mathrm{C}$ (45 $\left.\mathrm{mCi} / \mathrm{mmole}\right)$ were purchased from New England Nuclear Corp., Boston, Mass. Portions of ${ }^{3} \mathrm{H}$ and ${ }^{14} \mathrm{C}$-labeled steroids were combined and radiochemical purity demonstrated before use by constancy of ${ }^{8} \mathrm{H}:{ }^{14} \mathrm{C}$ ratio through a series of derivatives as shown in Fig. 1. Estrone-3- $\mathrm{NH}_{4}$-sulfate- $4-{ }^{14} \mathrm{C}(45 \mathrm{mCi} / \mathrm{mmole})$ was prepared from estrone- $4{ }^{14} \mathrm{C}(45 \mathrm{mCi} / \mathrm{mmole})$ by a modification of the method of Mumma, Hoiberg, and Weber (4). Estrone4-14 $\mathrm{C}$ was dried in a $1 \mathrm{ml}$ centrifuge tube and redissolved in $20 \mu \mathrm{l}$ of dimethyl formamide (DMF) and chilled to $0^{\circ} \mathrm{C}$ in an ice-water bath. To the estrone in DMF, $10 \mu \mathrm{l}$ of chilled $14 \%$ concentrated sulfuric acid in DMF ( $\mathrm{v} / \mathrm{v}$ ) was added and mixed quickly with a vortex mixer. This was followed by addition of $25 \mu \mathrm{l}$ of $3 \mathrm{M}$ dicyclohexylcarbodiimide (DCC) in DMF prepared by adding $0.150 \mathrm{~g}$ DCC to $0.0240 \mathrm{ml} \mathrm{DMF}$. After mixing, the solution turned a thick white, and was then incubated at $0^{\circ} \mathrm{C}$ for an additional $15 \mathrm{~min}$. $1 \mathrm{ml}$ of $1 \mathrm{M} \mathrm{NH}{ }_{4} \mathrm{OH}$ in methanol was added, the solution mixed, and centrifuged. The supernatant was chromatographed by thin-layer chromatography (TLC) (5) to separate monosulfate from free steroids.

Radiochemical purity of estrone-3-sulfate- $4-{ }^{14} \mathrm{C}$ was demonstrated by mixing it with portions of estrone-3- $\mathrm{NH}_{4-}$ sulfate- $6,7-{ }^{3} \mathrm{H}$ and demonstrating constancy of ${ }^{8} \mathrm{H}:{ }^{14} \mathrm{C}$ ratios through TLC, isolation, solvolysis of $E_{1} S$, and recrystallization of estrone to constant specific activity. Before any study involving the use of estrone sulfate- ${ }^{3} \mathrm{H}$, the steroid was dissolved in sterile saline and preextracted with ether to re-

1020 The Journal of Clinical Investigation Volume 511972 


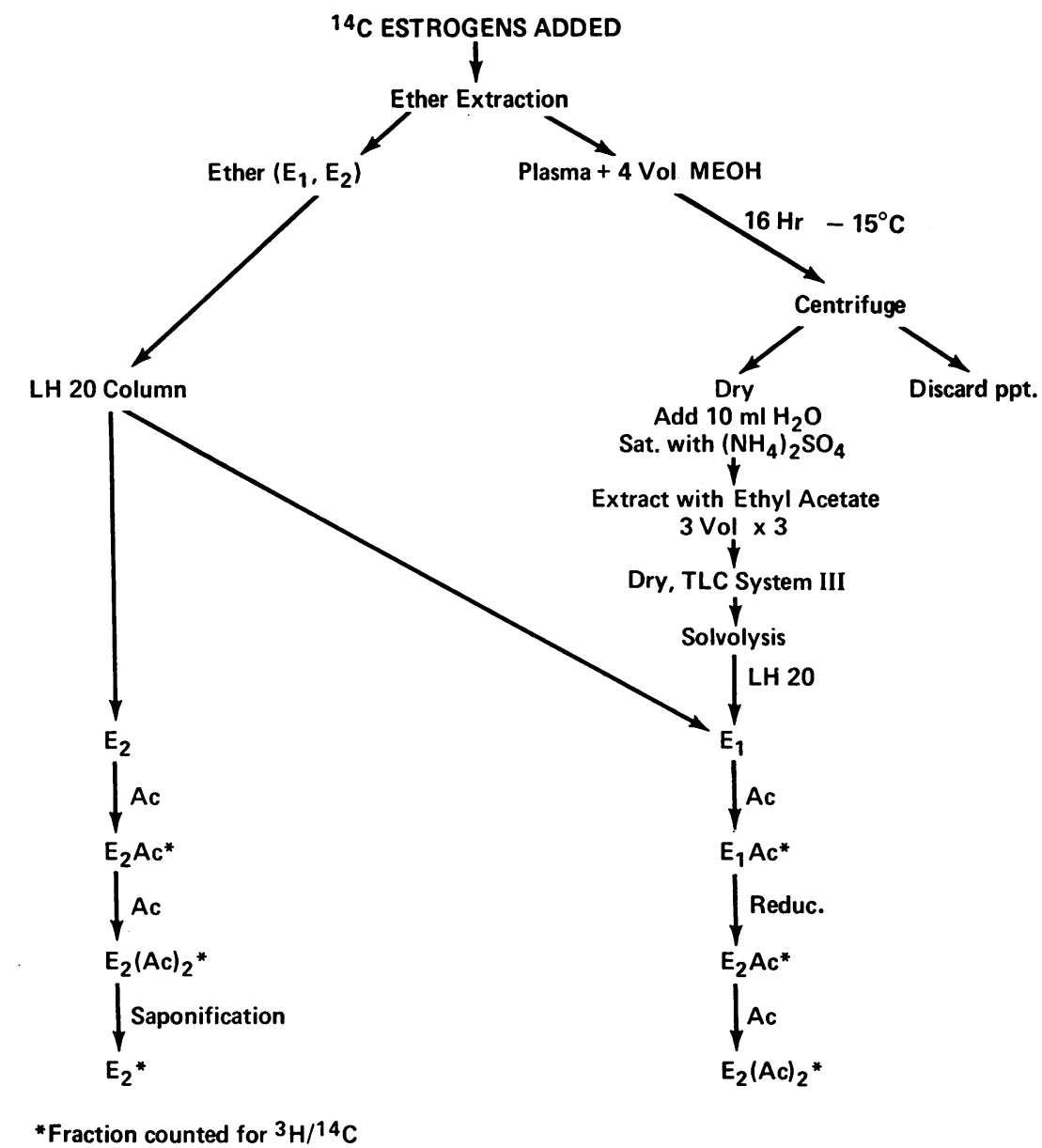

FIGURE 1 Flow chart for measurement of tritium in plasma estrone, estradiol, and $E_{1} S$ during infusion of ${ }^{3} \mathrm{H}$ estrogens.

move any contaminating free estrogen. The ether phase was discarded, excess ether removed by an air stream, and portions taken in triplicate for determination of $\mathrm{E}_{1} \mathrm{~S}_{-}{ }^{8} \mathrm{H}$. An appropriate volume of sterile saline was then drawn up in a glass syringe for injection or addition to an infusion bottle.

Chromatoquality estrone and estradiol (Calbiochem, Los Angeles, Calif.) were used without further recrystallization. Solvents were spectroquality and used without further purification. TLC was performed on Merck precoated silica gel GF-254 $20 \times 20 \mathrm{~cm}$ glass plates (Merck Chemical Division, Merck \& Co., Inc., Rahway, N. J.). The systems used for separations of various steroid and the $R_{R}$ values are previously described $(3,5,6)$. Column chromatography was performed on small Sephadex LH-20 columns (Pharmacia Fine Chemicals Inc., Piscataway, N. J.) which separate $E_{1}$ and $\mathrm{E}_{2}$ as described previously (5).

Subjects. Normal subjects, (Nos. 2-18), ages 18-30 yr were hospitalized at the National Institutes of Health and received no medications. Each woman had normal cyclic menses. Subject 16 was a 28 year old euthyroid subject with a benign thyroid nodule. Subject 1 was a normal man, age 48 , in good health.

Clearance rates. Determinations of metabolic clearance rate (MCR) were started at 7:30 a.m. with subjects re- maining in the basal state until the end of the study. The infusion techniques were performed as described previously (7).

All short infusions were begun with a $10 \mu \mathrm{Ci}$ bolus given i.v. over $1 \mathrm{~min}, 30 \mathrm{~min}$ later an infusion of approximately $10 \mu \mathrm{Ci} / \mathrm{hr}$ was begun and maintained at a constant rate until the end of the study. The duration of the short infusions was usually $165 \mathrm{~min}$ from the time of the bolus and varied from $135 \mathrm{~min}$ in earlier studies to $210 \mathrm{~min}$ in later studies, $30-40 \mathrm{ml}$ of blood was drawn at various times after the bolus was given; the heparinized plasma was separated by centrifugation and stored at $-16^{\circ} \mathrm{C}$ until extracted.

To measure the MCR of $\mathrm{E}_{1} \mathrm{~S}, 20-40 \mu \mathrm{ci}$ of $\mathrm{E}_{1} \mathrm{~S}^{3}{ }^{3} \mathrm{H}$ was injected over $1 \mathrm{~min}$ at 9:00 a.m. via an antecubital vein. 10-ml blood samples were taken at $\frac{1}{2}, 1,2,4,6$, and $8 \mathrm{hr}$ and $20-35-\mathrm{ml}$ blood samples were taken at 11, 14, 19, and $24 \mathrm{hr}$. Blood was heparinized, centrifuged immediately, and the plasma frozen at $-15^{\circ} \mathrm{C}$ until extracted. Subjects were kept at bed rest with bathroom privileges and fed light meals as desired for the duration of the study except for subjects 1 and 2, who were allowed normal daily activities.

Calculations. The symbols and calculations for the several parameters of the system are essentially those used by Horton and Tait (8). Since all measurements were made in 


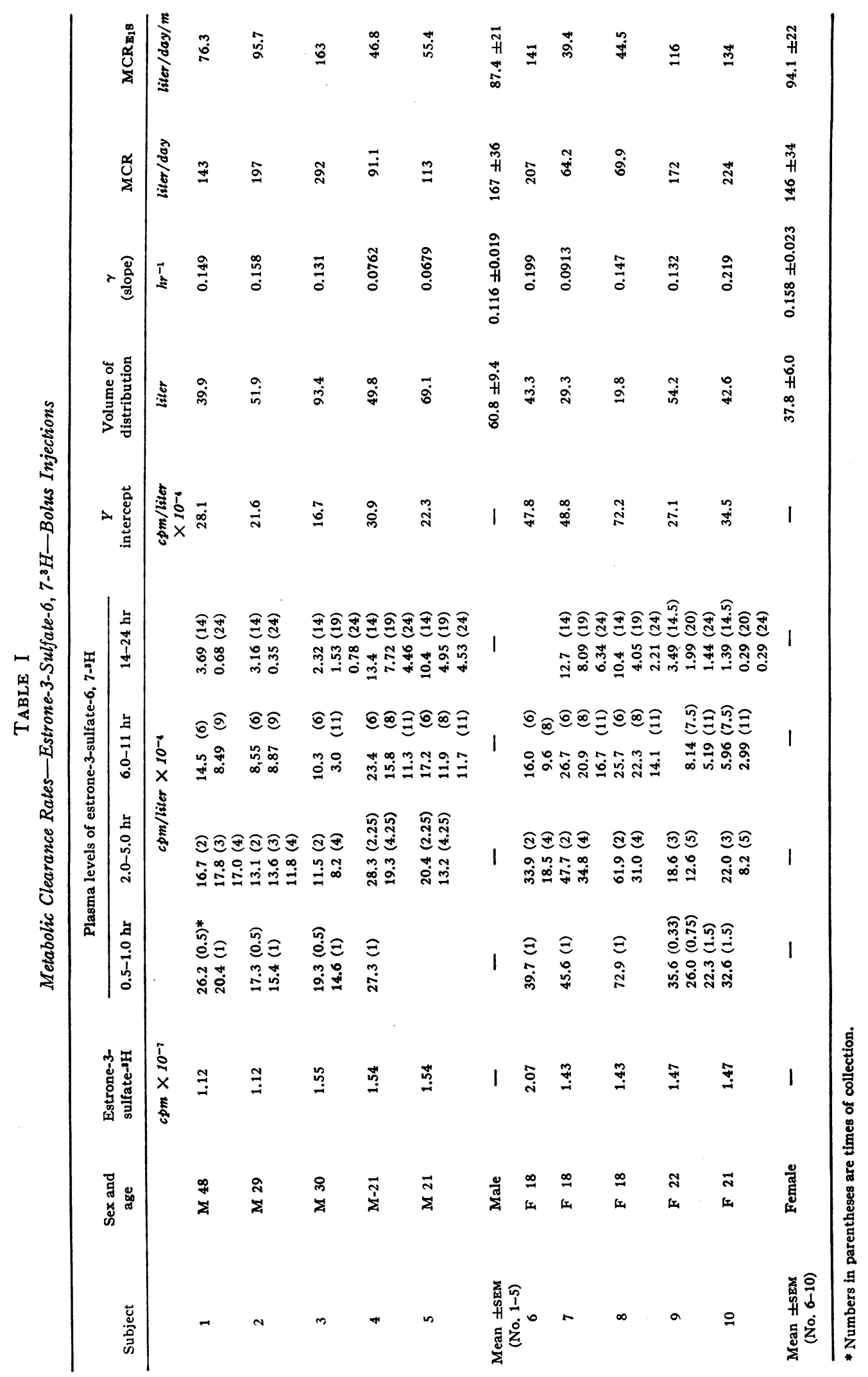

1022

H. J. Ruder, L. Loriaux, and M. B. Lipsett 
plasma, the compartment is not indicated and the superscript indicates the steroids. Production rate equals MCR $\times$ plasma concentration. The conversion ratio, $\mathrm{C}^{\mathrm{E}_{1} \mathrm{E}_{1} \mathrm{~s}}$, is the ratio of radioactivity of product $E_{1} S$, to precursor, $E_{1}$, when equilibrium has been reached. The transfer factor, $\rho^{\mathbb{R}_{1} \mathbb{E}_{1} \mathrm{~S}}=$ $\mathrm{C}^{\mathbf{E}_{1} \mathbf{B}_{1} \mathbf{8}} \times \mathrm{MCR}_{\mathrm{E}_{1} \mathbf{8}} / \mathrm{MCR}_{\mathrm{E}_{1}}$, is the fraction of plasma $\mathrm{E}_{1}$ production rate converted to plasma $E_{1} S$.

Isolation of labeled estrogens. All plasma samples were processed within $3 \mathrm{wk}$ of collection and were treated identically, as shown in Fig. 1. To monitor recovery appropriate amounts $(100-1000 \mathrm{cpm})$ of ${ }^{14} \mathrm{C}$ estrogens were added to each plasma sample. All samples from a single study were processed together. After alkalinizing with 4 drops of $\mathrm{NH}_{4} \mathrm{OH}$, the plasma was extracted three times with 2 vol of ether. The ether extracts containing the neutral steroids were under air and stored until further processing in $5 \mathrm{ml}$ of absolute ethanol at $-15^{\circ} \mathrm{C}$. Previous tests had shown that only $1-2 \%$ of estrone sulfate is removed by the ether, probably in the small amount of water soluble in the ether. Estrone sulfate proved stable in the cold so that any contaminating $E_{1} S$ was separated from free estrogens by the subsequent column chromatography. The ether-extracied plasma containing the conjugated steroids, including $E_{1} S$, was warmed to $40^{\circ} \mathrm{C}$ and the residual ether removed under an air stream. Recovery of estrone sulfate was found to be inversely related to the quantity of ether remaining at this point. To the plasma was then added 4 vol of absolute methanol to precipitate proteins. Each sample was mixed by shaking for $30 \mathrm{sec}$ and stored at $-15^{\circ} \mathrm{C}$ for at least $16 \mathrm{hr}$ to precipitate lipids. Centrifugation and decanting of the supernatant yielded a yellow methanol solution which contained about $80 \%$ of the starting $\mathrm{E}_{1} \mathrm{~S}$. After addition of 4 more drops of $\mathrm{NH}_{4} \mathrm{OH}$, samples could be stored indefinitely in the cold until further processing.

Processing $E_{1} S$. After $16 \mathrm{hr}$ at $-15^{\circ} \mathrm{C}$, the methanolprecipitated plasma was centrifuged in $100-\mathrm{ml}$ centrifuge tubes at $2000 \mathrm{~g}$ for $20 \mathrm{~min}$. The yellow supernatant was decanted and either stored as described above or processed. The supernatant was dried under vacuum until only 2-5 ml of cloudy yellow water remained. This was quantitatively transferred to a $40 \mathrm{ml}$ glass-stoppered tube (final vol. $=10$ $\mathrm{ml} \mathrm{H}_{2} \mathrm{O}$ ), alkalinized with 5 drops of concentrated $\mathrm{NH}_{4} \mathrm{OH}$, saturated with dry $\left(\mathrm{NH}_{4}\right)_{2} \mathrm{SO}_{4}$, and extracted three times with 2 vol of ethyl acetate. The ethyl acetate quantitatively removed the $E_{1} S$. Recovery to this point is $60-70 \%$. The ethyl acetate was combined and reduced in volume, and the residue was spotted onto TLC plates and the monosulfate fraction isolated (5). Dehydroeipandrosterone sulfate (DHS) was used as a marker on both sides of the plate and the DHS identified by streaking with Allen's reagent. After elution from the TLC plate, the samples were dried and then resuspended in $0.2 \mathrm{ml}$ of absolute ethanol. Solvolysis was performed by addition of $5 \mathrm{ml}$ of $10 \%$ glacial acetic acid in ethyl acetate and incubation in a tightly capped tube for $16 \mathrm{hr}$ at $50^{\circ} \mathrm{C}$. The solvents were removed under $\mathrm{N}_{2}$ at $40^{\circ} \mathrm{C}$. No washing was necessary, and previous tests demonstrated that the estrone was not altered by this procedure. From this point on, derivative formation and portioning for determination of ${ }^{3} \mathrm{H}:{ }^{14} \mathrm{C}$ ratios is as previously described for estrone (6). Recovery of $\mathrm{E}_{1} \mathrm{~S}-{ }^{14} \mathrm{C}$ to the isolation of estrone averaged $50 \%$. In sample studies this procedure was shown to separate completely $E_{1}$ and $E_{1} S$ in plasma since addition of a 100 -fold excess of $\mathrm{E}_{1}{ }^{-}{ }^{3} \mathrm{H}$ did not influence the values obtained for tritiated $E_{1} S$; and conversely, addition of 100 -fold excess of $\mathrm{E}_{1} \mathrm{~S}-{ }^{8} \mathrm{H}$ did not influence the values obtained for tritiated $E_{1}$.

Processing $E_{1}$ and $E_{2}$. Sample tubes containing neutral steroids in ethanol were dried under $\mathrm{N}_{2}$ at $40^{\circ} \mathrm{C}$ and estrone and estradiol separated by column chromatography on Sephadex LH-20 (5). To the appropriate fraction was added $200 \mu \mathrm{g}$ estrone or estradiol, and derivative formation carried out as shown on Fig. 1 and as previously described

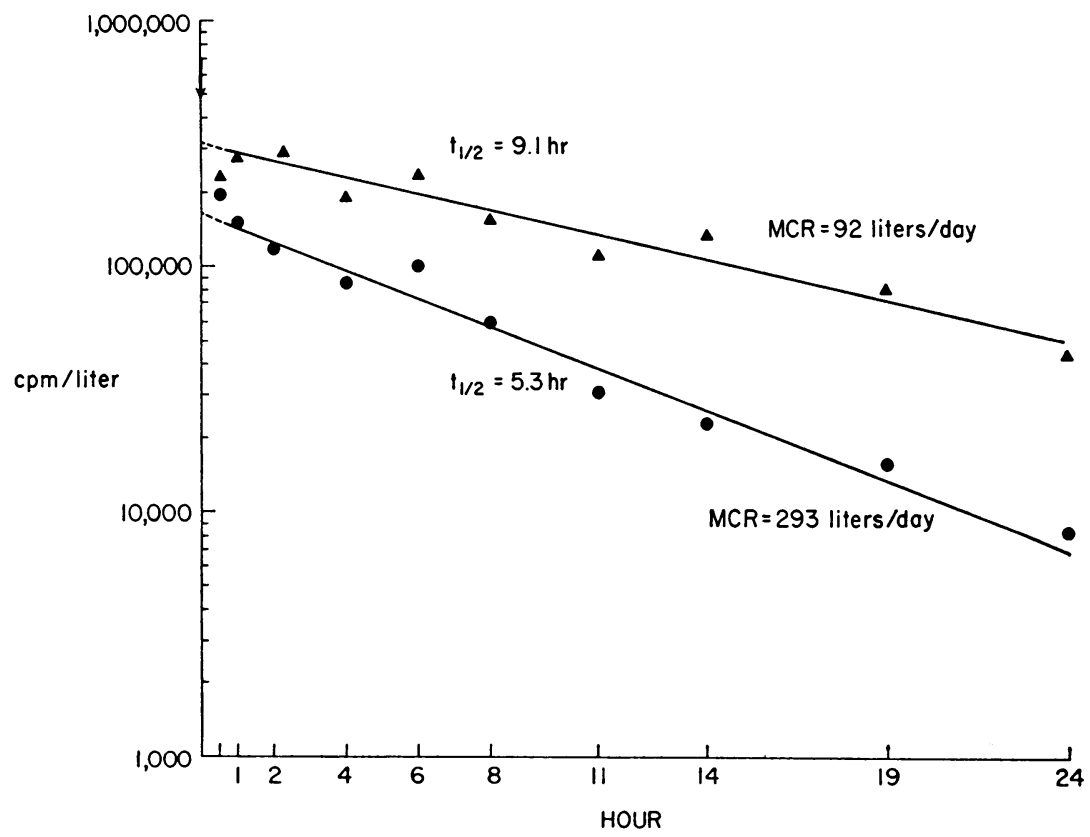

Figure 2 Representative data from a low and high $\mathrm{MCR}_{\mathrm{E}_{\mid} \mathrm{s}}$. Infusion started at time 0 . The points are the data points; the lines were determined by a computer program. 


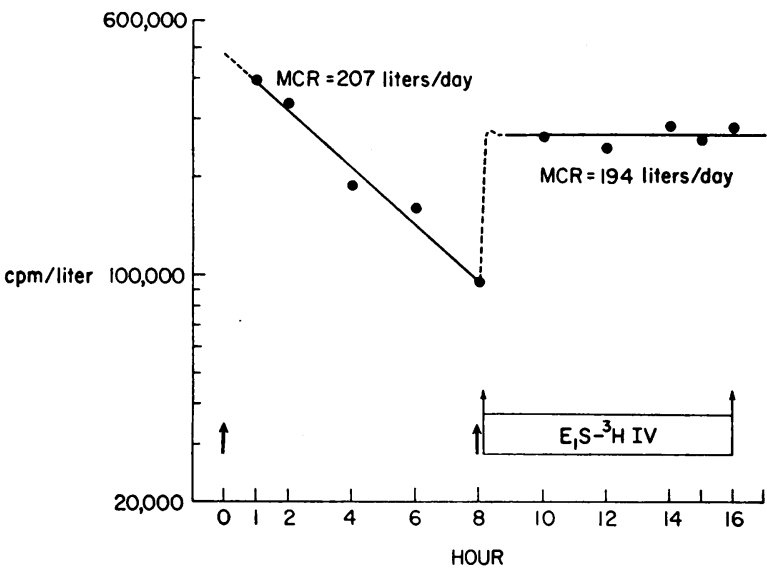

FIGURE $3 \mathrm{MCR}_{\mathrm{E}_{1} \mathrm{~s}}$ measured after injection of $\mathrm{E}_{1} \mathrm{~S}-{ }^{8} \mathrm{H}$ at time 0 and at $8 \mathrm{hr}$ followed then by a continuous infusion of $\mathrm{E}_{1} \mathrm{~S}-{ }^{8} \mathrm{H}$ (subject 6 ).

$(3,6)$. After the first four studies were completed, it was evident that in no case did ${ }^{3} \mathrm{H}:{ }^{14} \mathrm{C}$ ratios change significantly after the first derivative was isolated, and that in all cases the ${ }^{8} \mathrm{H}:{ }^{14} \mathrm{C}$ ratio of the first derivative was the same as that of the final derivative. Hence, thereafter, only two derivatives were counted; the second was the same as the first in the remainder of the studies. In no instance was fewer than $15 \mathrm{cpm}$ above background of ${ }^{14} \mathrm{C}$ present in the second derivative, and except in the case of the $E_{2}$ levels during $E_{1} S$ infusions where conversion to $\mathrm{E}_{2}$ was quite low, the ${ }^{8} \mathrm{H}:{ }^{14} \mathrm{C}$ ratio was greater than 1.0 and less than 8.0 in all samples.

Estrone sulfate binding to red blood cells $(R B C)$. Portions of packed $\mathrm{RBC}$ taken during $\mathrm{E}_{1} \mathrm{~S}-{ }^{3} \mathrm{H}$ infusions were examined for binding of $E_{1} S$. We found little $(<5 \%)$ of the $\mathrm{E}_{1} \mathrm{~S}-{ }^{8} \mathrm{H}$ present in whole blood to be associated with RBC.

Counting methods. Radioactivity was measured as previously described $(3,6)$. All samples were counted to either a minimum of 3000 counts in the carbon channel or for 100 min. Samples were spot checked for differences in quenching and none were found.

Plasma estrogen concentrations. Methods for measurement of plasma concentration of $E_{1}, E_{2}$, and $E_{1} S$ have been described (5) and normal values for our laboratory are shown in Table III. These values include all patients used in the infusion studies and agree well with those obtained by others (9-11).

Plasma concentration of estradiol monosulfate. To determine if estradiol monosulfate was an important metabolite of estradiol or if it was present in plasma in significant amounts, the following studies were performed. (a) We attempted to isolate $\mathrm{E}_{2} \mathrm{~S}-{ }^{8} \mathrm{H}$ from plasma obtained from two subjects during $\mathrm{E}_{2}{ }^{8} \mathrm{H}$ infusion. The entire monosulfate fraction was solvolyzed and the $E_{1}$ and $E_{2}$ fractions isolated. Radiochemical purity was demonstrated only for $\mathrm{E}_{1}{ }^{3} \mathrm{H}$, but tritium present in the $\mathrm{E}_{2}-{ }^{8} \mathrm{H}$ fraction was approximately $10 \%$ that present as $\mathrm{E}_{1}{ }^{8} \mathrm{H}$. Hence conversion of $E_{2}$ to $E_{2} S$ could occur maximally at only the rate of $\mathrm{E}_{2}$ conversion to $\mathrm{E}_{1} \mathrm{~S}$. (b) 15 random plasma samples were examined for $E_{2}$ monosulfate. No recovery trace was available for $\mathrm{E}_{2}{ }^{8} \mathrm{H}$-3-sulfate or $\mathrm{E}_{2}{ }^{-8} \mathrm{H}-17$-sulfate, but recovery was assumed to be similar to that for $\mathrm{E}_{1} \mathrm{~S}$ determined simultaneously. After solvolysis of the monosulfate fraction from TLC, both $E_{1}$ and $E_{2}$ were isolated on Sephadex LH-20. The $E_{2}$ fractions were assayed and found to be indistinguishable from blank values $(25-50 \mathrm{pg})$. Assuming the same recovery for $E_{2}$ monosulfate as for $E_{1} S$, this would mean that $\mathrm{E}_{2} \mathrm{~S}$ was present at less than $100-150 \mathrm{pg} / \mathrm{ml}$ plasma whereas $E_{1} S$ was measured at concentrations of 250 $1000 \mathrm{pg} / \mathrm{ml}$.

\section{RESULTS}

$E_{1} S$ metabolic clearance rates. The data for the disappearance of $\mathrm{E}_{1} \mathrm{~S}_{-}{ }^{3} \mathrm{H}$ from plasma are shown in Table I. When the data for each subject were analyzed, it was found that in all cases, disappearance curves could be fitted by a single straight line, consistent with a one-compartment system described by a single $Y$ intercept (volume of distribution) and a single slope (fractional pool turnover rate). Two representative studies are shown in Fig. 2. The lines of best fit were calculated by computer program, and the points shown are the data points. Metabolic clearance rates were calculated, assuming a one-compartment model, by the formula $\mathrm{MCR}=\mathrm{V} \gamma$, where $\mathrm{V}=$ the volume of distribution and $\gamma=$ fractional pool turnover rate per unit

TABLE II

Plasma Concentrations and Production Rates $(P R)$ of Estrone, Estradiol, and Estrone-3-Sulfate

\begin{tabular}{|c|c|c|c|c|c|c|c|c|c|}
\hline & $\mathrm{E}_{1} \mathrm{~S} \mathrm{MCR}$ & $\mathrm{E}_{1} \mathrm{~S}$ & $\mathrm{E}_{1} \mathrm{~S}$ PR & $\mathrm{E}_{1} \mathrm{MCR}^{*}$ & $\mathrm{E}_{1}$ & $\mathrm{E}_{1} \mathrm{PR}$ & $\mathrm{E}_{2} \mathrm{MCR}^{*}$ & $\mathrm{E}_{2}$ & $\mathrm{E}_{2} \mathrm{PR}$ \\
\hline & liter/day & $p g / m l$ & $\mu g / d a y$ & liter/day & $p g / m l$ & $\mu g / d a y$ & liter/day & $p g / m l$ & $\mu g / d a y$ \\
\hline Men & 167 & 460 & 77 & $\begin{array}{c}2380 \\
(1177) \ddagger\end{array}$ & 47 & 112 & $\begin{array}{l}1700 \\
(892)\end{array}$ & 34 & 58 \\
\hline \multicolumn{10}{|l|}{ Women } \\
\hline Follicular phase & 146 & 654 & 95 & $\begin{array}{c}1750 \\
(1070)\end{array}$ & 62 & 109 & $\begin{array}{l}1055 \\
(642)\end{array}$ & 110 & 116 \\
\hline \multicolumn{10}{|l|}{ Women } \\
\hline Luteal phase & 146 & 1,246 & 182 & 1750 & 86 & 151 & 1055 & 193 & 204 \\
\hline
\end{tabular}

* Average MCR for this laboratory.

$\ddagger$ Numbers in parentheses, average MCR for this laboratory, expressed_as liter/day per $\mathrm{m}^{2}$. 


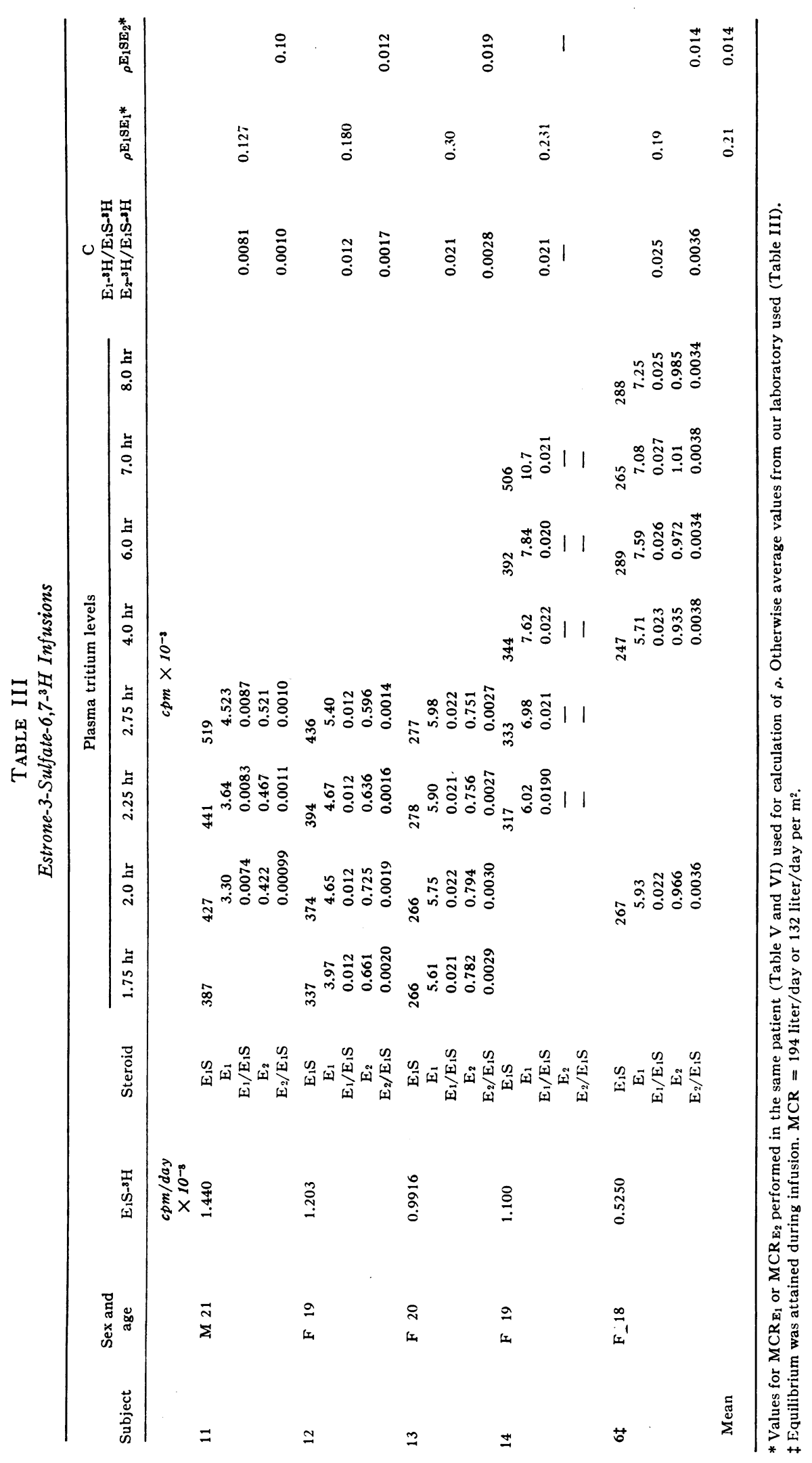

Estrone Sulfate: Production Rate and Metabolism in Man 
TABLE IV

Estrone-6,7.

\begin{tabular}{|c|c|c|c|c|c|c|}
\hline \multirow[b]{2}{*}{ Subject } & \multirow{2}{*}{$\begin{array}{l}\text { Sex and } \\
\text { age }\end{array}$} & \multirow{2}{*}{$\begin{array}{l}\text { Estrone- } \\
\text { 'H infusion }\end{array}$} & \multirow[b]{2}{*}{${ }^{8} \mathrm{H}$-steroid } & \multicolumn{3}{|c|}{ Plasma tritium levels } \\
\hline & & & & $1.75 \mathrm{hr}$ & $2.0 \mathrm{hr}$ & $2.25 \mathrm{hr}$ \\
\hline & & $c p m / d a y \times 10^{-8}$ & & \multicolumn{3}{|c|}{$c p m \times 10^{-8} / l i l e r$} \\
\hline 【11】 & M 21 & 1.048 & $\begin{array}{l}E_{1} \\
E_{1} S\end{array}$ & $\begin{array}{l}41.7 \\
86.5\end{array}$ & $\begin{array}{l}44.6 \\
99.4\end{array}$ & $\begin{array}{c}47.2 \\
110\end{array}$ \\
\hline 12 & F 19 & 0.965 & $\begin{array}{l}E_{1} \\
E_{1} S\end{array}$ & $\begin{array}{l}45.4 \\
89.3\end{array}$ & $\begin{array}{l}43.5 \\
101\end{array}$ & $\begin{array}{c}43.5 \\
117\end{array}$ \\
\hline 13 & F 20 & 0.992 & $\begin{array}{l}E_{1} \\
E_{1} S\end{array}$ & $\begin{array}{l}43.8 \\
60.6\end{array}$ & $\begin{array}{l}45.2 \\
67.0\end{array}$ & $\begin{array}{l}49.0 \\
75.6\end{array}$ \\
\hline 8 & F 18 & 1.08 & $\begin{array}{l}E_{1} \\
E_{1} S\end{array}$ & & $\begin{array}{l}(59.2) \\
222\end{array}$ & \\
\hline Mean & & & & & & \\
\hline
\end{tabular}

* Value for $\mathrm{MCR}_{\mathrm{E}_{1}}$ s performed in the same patient (Table II) used for calculation of $\rho$; otherwise average values for our laboratory used (Table III).

time. The average $\mathrm{MCR}_{\mathrm{E}_{18} \mathrm{~s}}$ in five men was 167 liter/ day or 87.4 liter/day per $\mathrm{m}^{2}$. The average MCR of five women was 146 liter/day or 94.1 liter/day per $\mathrm{m}^{2}$. The large differences among normal subjects are related both to differences in fractional turnover rate, $\gamma$ (range 0.0679-0.219 pools/hr) and volume of distribution, V (range 20-93 liters). The range of volumes of distribution was roughly correlated with body surface area.

The validity of calculation of $M \mathrm{CR}_{\mathrm{E}_{1}} \mathrm{~s}$ based on the assumption of a one-compartment system was tested by comparing in the same subject the MCR obtained in this way with that obtained by the constant infusion technique. In this study, we injected a bolus of $E_{1} S$ into a normal subject. No. 6 , and established a $\mathrm{MCR}_{\mathrm{E}_{1} 8}$ from the plasma disappearance curve over $8 \mathrm{hr}$. Subsequently, a calculated bolus of $\mathrm{E}_{1} \mathrm{~S}-{ }^{\mathrm{B}} \mathrm{H}$ was given followed by a continuous infusion of $\mathrm{E}_{1} \mathrm{~S}-{ }^{3} \mathrm{H}$ for a further $8 \mathrm{hr}$ achieving a constant plasma level of $\mathrm{E}_{1} \mathrm{~S}-{ }^{3} \mathrm{H}$ (Fig. 3). From the data obtained after the injection of $\mathrm{E}_{1} \mathrm{~S}^{3}{ }^{3} \mathrm{H}$ (Table I), a MCR of 207 liter/day was calculated. The MCR calculated from the constant infusion data (Table III) was 194 liter/day. These two MCR are not different.

The production rate of $E_{1} S$ was calculated from the $M C R_{E_{1}}$ and the measured plasma concentrations of $E_{1} S$ (Table II). Average values for $\mathrm{MCR}$ and plasma $\mathrm{E}_{1} \mathrm{~S}$ concentrations in both men and women were used. In men, $E_{1} S$ production averaged $77 \mu \mathrm{g} /$ day, not greatly different from $E_{1}$ and $E_{2}$ production rates. In women, $\mathrm{E}_{1} \mathrm{~S}$ production averaged $95 \mu \mathrm{g} /$ day during the early follicular phase; and $182 \mu \mathrm{g} /$ day during the luteal phase. Follicular and luteal phase $\mathrm{E}_{1} \mathrm{~S}$ production rates are compared with follicular and luteal $E_{1}$ and $E_{2}$ production rates (Table II). To convert $\mathrm{E}_{1} \mathrm{~S}$ production rates to equivalent $E_{1}$ production rates, multiply $E_{1} S$ values by 0.71 .

Conversion ratios. $\mathrm{C}^{\mathrm{B}_{1} \mathrm{SE}_{1}}$ and $\mathrm{C}^{\mathrm{B}_{1} \mathrm{SB}_{2}}$ were measured in five subjects (Table III). Shown in Table III are the plasma levels of tritium in $\mathrm{E}_{1}, \mathrm{E}_{2}$, and $\mathrm{E}_{1} \mathrm{~S}$; conversion ratios have been calculated at each time point. Though plasma levels of $\mathrm{E}_{1} \mathrm{~S}_{-}{ }^{3} \mathrm{H}, \mathrm{E}_{1}{ }^{8} \mathrm{H}$, and $\mathrm{E}_{2}{ }^{-}{ }^{8} \mathrm{H}$ are increasing, the conversion ratios are constant and appear to represent equilibrium values. Each series of conversion ratios was examined for systematic trends or deviations from the mean. Only in subject 11 was there a suggestion that $\mathrm{C}^{\mathrm{E}_{1} \mathrm{sE}_{1}}$ was increasing during the period of observation. In subject 6, plasma levels of $\mathrm{E}_{1}{ }^{-} \mathrm{H}$ and $\mathrm{E}_{1} \mathrm{~S}_{-}{ }^{8} \mathrm{H}$ reached equilibrium as did the conversion ratios and the conversion ratio of 0.025 , was the same as the average of the other subjects. The conversion ratio $\left(\mathrm{C}^{\mathrm{B}_{1} \mathbf{s B}_{1}}\right)$ averaged 0.017 in five studies. Transfer factors $(\rho)$ were calculated using these conversion ratios and values for $M C R_{\mathbb{F}_{1}}$ and $M C R_{\mathbb{E}_{1} \mathrm{~s}}$ either measured in the same subject (Table IV) or using average values from our laboratory (Table III) (3). Transfer factor $\left(\rho^{\mathrm{E}_{1} \mathrm{SE}_{1}}\right)$ averaged 0.21 (range 0.13 0.30) (Table III).

The conversion ratio $\left(\mathrm{C}^{\mathrm{B}_{1} \mathrm{st}_{2}}\right)$ averaged 0.0023 in four studies, about $1 / 10$ that for the conversion of $E_{1} S$ to estrone. Transfer factors were then calculated using these conversion ratios and values for $\mathrm{MCR}_{\mathbb{m}_{2}}$ and $M \mathrm{MCR}_{\mathrm{E}_{1} \mathrm{~S}}$ either measured in the same subject (Table V) or using average values from our laboratory (Table II) (3). The transfer factor $\left(\rho^{\mathrm{I}_{1} \mathrm{Sm}_{2}}\right)$ averaged 0.014 (range 0.010-0.019) (Table III).

Since $E_{1} S$ is effective by mouth in contrast to estrone and estradiol, the metabolism of $\mathrm{E}_{1} \mathrm{~S}$ taken orally to 


\begin{tabular}{|c|c|c|c|c|c|c|c|}
\hline \multicolumn{3}{|c|}{ Plasma tritium levels } & \multirow{2}{*}{$\begin{array}{l}\text { Equilibrium } \\
{ }^{3} \mathrm{H} \text { levels }\end{array}$} & \multirow{2}{*}{$\begin{array}{c}C E_{1} E_{1} S \\
E_{1} S^{-3} H / E_{1-3} H\end{array}$} & \multirow[b]{2}{*}{$\mathrm{MCR}_{\mathrm{E}_{1}}$} & \multirow[b]{2}{*}{$\mathrm{MCR}_{\mathrm{E}_{1}}$} & \multirow[b]{2}{*}{$\rho \mathrm{E}_{1} \mathrm{E}_{1} \mathrm{~S}^{\prime}$} \\
\hline $2.75 \mathrm{hr}$ & $3.0 \mathrm{hr}$ & $3.5 \mathrm{hr}$ & & & & & \\
\hline \multicolumn{3}{|c|}{$c p m \times 10^{-3} /$ liter } & $\mathrm{cpm} /$ liter $\times 10^{-3}$ & \multirow{3}{*}{10.3} & \multirow{3}{*}{$\begin{array}{c}\text { liter/day } \\
2290\end{array}$} & \multicolumn{2}{|l|}{ liter $/$ day $/ m^{2}$} \\
\hline 49.2 & & & 45.7 & & & 1350 & 0.67 \\
\hline 123 & & & 471 & & & & \\
\hline 45.0 & & & 44.3 & 8.68 & 2180 & 1400 & 0.58 \\
\hline 142 & & & 385 & & & & \\
\hline 47.4 & & & 46.3 & 5.24 & 2140 & 1310 & 0.38 \\
\hline \multirow[t]{4}{*}{83.2} & & & 247 & & & & \\
\hline & 66.7 & 67.6 & 67.2 & 12.4 & 1610 & 1020 & 0.54 \\
\hline & 288 & 335 & 833 & & & & \\
\hline & & & & 9.18 & & & 0.54 \\
\hline
\end{tabular}

plasma $\mathrm{E}_{1} \mathrm{~S}$, estrone, and estradiol was studied. When $30 \mu \mathrm{Ci}$ of $\mathrm{E}_{1} \mathrm{~S}-{ }^{3} \mathrm{H}$ was given by mouth. there was a prompt rise in plasma levels of tritiated $\mathrm{E}_{1} \mathrm{~S}$, peaking around $1 \mathrm{hr}$ as shown in Fig. 4. Plasma levels of tritiated $\mathrm{E}_{1}$ and $\mathrm{E}_{2}$ were $1.0 \%$ and $0.1 \%$, respectively, that of $\mathrm{E}_{1} \mathrm{~S}-{ }^{3} \mathrm{H}$, although $\mathrm{E}_{2}{ }^{3} \mathrm{H}$ was detectable only at $80 \mathrm{~min}$. These values are in close agreement with the conversion ratios found during i.v. infusions of tritiated $\mathrm{E}_{1} \mathrm{~S}$ shown in Table III.

Conversion of $E_{1}$ to $E_{1} S$. The data from the estrone${ }^{3} \mathrm{H}$ infusions are shown in Table IV. Plasma level of the infused estrone became constant in all cases. However, conversion of estrone to $\mathrm{E}_{1} \mathrm{~S}$ did not reach equilibrium in any infusion, as shown by increasing plasma levels of $\mathrm{E}_{1} \mathrm{~S}-{ }^{3} \mathrm{H}$. Thus the conversion ratio, could not be calculated directly since equilibrium conditions were not met. Estimates of equilibrium values for estrone-3sulfate and hence conversion ratios, $\mathrm{C}^{\mathrm{E}_{1}{ }_{1} \mathrm{~s}}$, were calculated using the formula,

$$
C^{E_{1} E_{1} S}=\frac{E_{1} S_{t x}-{ }^{3} H}{\left(E_{1}-{ }^{3} H\right)\left(1-e^{-\gamma T_{x}}\right)}, \quad \text { (see Appendix) }
$$

where $\mathrm{E}_{1}-{ }^{3} \mathrm{H}$ is the equilibrium value for $\mathrm{E}_{1}-{ }^{3} \mathrm{H}$ during $\mathrm{E}_{1}-{ }^{3} \mathrm{H}$ infusions and $\mathrm{E}_{1} \mathrm{~S}_{\mathrm{t}_{\mathbf{x}}}{ }^{8} \mathrm{H}$ is the plasma level of tritium in $\mathrm{E}_{1} \mathrm{~S}$ at time $\mathrm{T}_{\mathbf{x}} ; e$ is the natural logarithm, $T_{x}$ is the time after beginning the infusion; and $\gamma$ is the fractional pool turnover of $E_{1} S$ per unit time. In subject $8, \gamma$ was measured directly and average values for $\gamma$ from Table II were used for subjects 11-13. In one subject, No. 18, in whom MCR $\mathrm{E}_{1}, \mathrm{MCR}_{\mathrm{E}_{1} \mathrm{~S}}$, and plasma levels of all estrogens had been measured, the SAAM program of Berman and Weiss (12) was used to perform a computer simulation and calculate equi- librium values for $E_{1} S$ during a short $E_{1}$ infusion. There was agreement between this value and that obtained by the extrapolation shown above.

The average of four determinations of $\mathrm{C}^{\mathrm{E}_{1} \mathrm{E}_{1} \mathrm{~s}}$ in plasma was 9.2 (range 5.34-12.4) (Table IV). Transfer factors were calculated using the conversion ratios, measured values for $\mathrm{MCR}_{\mathrm{E}_{1}}$, and average male and female $M C R_{E_{1}}$ from Table I (an $\mathrm{MCR}_{\mathbf{E}_{1} \mathbf{S}}$ was measured

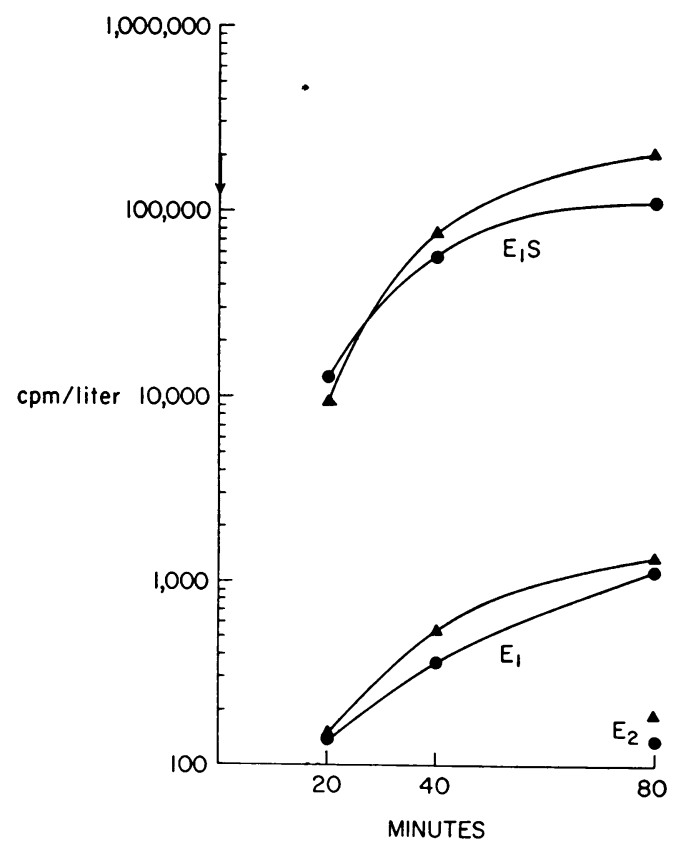

Figure 4 Plasma levels of tritium in $\mathrm{E}_{1} \mathrm{~S}$; estrone $\left(\mathrm{E}_{1}\right)$, and estradiol $\left(\mathrm{E}_{2}\right)$ after oral administration of $\mathrm{E}_{1} \mathrm{~S}-{ }^{3} \mathrm{H}$ at time 0 (subjects 1 and 2). 
TABLE V

Estradiol-6, 7-

\begin{tabular}{|c|c|c|c|c|c|c|c|}
\hline \multirow[b]{2}{*}{ Subject } & \multirow{2}{*}{$\begin{array}{l}\text { Sex and } \\
\text { age }\end{array}$} & \multirow{2}{*}{$\begin{array}{l}\text { Estradiol- } \\
{ }^{3} \mathrm{H} \text { infusion }\end{array}$} & \multirow[b]{2}{*}{${ }^{3} \mathrm{H}$-steroid } & \multicolumn{4}{|c|}{ Plasma tritium levels } \\
\hline & & & & $1.75 \mathrm{hr}$ & $2.0 \mathrm{hr}$ & $2.25 \mathrm{hr}$ & \\
\hline & & $c p m / d a y \times 10^{-8}$ & & & $c p m \times$ & $-\mathrm{s} /$ liter & \\
\hline 7 & F 18 & 1.32 & $\begin{array}{l}E_{2} \\
E_{1} S\end{array}$ & & $\begin{array}{l}111 \\
206\end{array}$ & & \\
\hline 9 & F 22 & 0.919 & $\begin{array}{l}\mathrm{E}_{2} \\
\mathrm{E}_{1} \mathrm{~S}\end{array}$ & & & & \\
\hline 15 & F 22 & 1.27 & $\begin{array}{l}E_{2} \\
E_{1} S\end{array}$ & $\begin{array}{l}140 \\
106\end{array}$ & $\begin{array}{l}129 \\
111\end{array}$ & $\begin{array}{l}136 \\
122\end{array}$ & $\begin{array}{l}148 \\
154\end{array}$ \\
\hline 16 & M 26 & 1.14 & $\begin{array}{l}E_{2} \\
E_{1} S\end{array}$ & $\begin{array}{l}69.3 \\
26.7\end{array}$ & $\begin{array}{l}73.2 \\
-\end{array}$ & $\begin{array}{l}72.1 \\
38.9\end{array}$ & \\
\hline 17 & M 26 & 1.06 & $\begin{array}{l}E_{2} \\
E_{1} S\end{array}$ & $\begin{array}{l}58.1 \\
135\end{array}$ & $\begin{array}{c}58.9 \\
167\end{array}$ & $\begin{array}{l}62.6 \\
211\end{array}$ & \\
\hline 18 & M 23 & 1.26 & $\begin{array}{l}E_{2} \\
E_{1} S\end{array}$ & $\begin{array}{l}60.1 \\
78.4\end{array}$ & $\begin{array}{l}60.9 \\
79.2\end{array}$ & $\begin{array}{c}64.9 \\
100\end{array}$ & \\
\hline Mean & & & & & & & \\
\hline
\end{tabular}

* Value for $C M R_{E s_{1}}$ performed in the same patient (Table II) used for calculation of $\rho$; otherwise average values for our laboratory used (Table III).

and used for calculations in subject 8). The transfer factor $\left(\rho^{\mathrm{E}_{1} \mathrm{E}_{1} \mathrm{~s}}\right)$ averaged 0.54 (Table IV).

Conversion of $E_{2}$ to $E_{1} S$. The data obtained from estradiol-6,7- ${ }^{3} \mathrm{H}$ infusions are shown in Table V. Plasma levels of the infused steroid, estradiol, were at equilibrium in all cases, but as with $E_{1}$ the conversion of $E_{2}$ to $\mathrm{E}_{1} \mathrm{~S}$ did not reach equilibrium. The extrapolation to equilibrium values was performed as for E1. Again, the SAAM program of Berman and Weiss (12) was used to confirm the validity of the estimates of equilibrium values calculated by the above formula. This was done in subject 7 in whom we had sufficient data about MCR and plasma estrogen concentrations to allow the computer to derive equilibrium solutions. There was good agreement between the two methods.

The average of six determinations of $C^{\mathrm{E}_{2} \mathrm{E}_{1} \mathbf{s}}$ is 7.1 ; range 2.19-13.6) (Table V). Transfer factors were calculated using these conversion ratios, actual measured values for $\mathrm{MCR}_{\mathrm{E}_{2}}$, and average male and female values for $M C R_{E_{1} s}$ from Table I (MCR $\mathbb{E}_{1}$ s was measured and used in the calculation of transfer factor in subjects 7 and 9$)$. The transfer factor $\left(\rho^{\mathbb{E}_{2}{ }_{1}}{ }_{1}\right)$ averaged 0.65 (Table V).

\section{DISCUSSION}

Estrone sulfate was identified in urine over 30 years ago but little is known of its role in the estrogen economy of the body. Although urinary estrogens are generally excreted as the glucuronide conjugates, in an occasional subject $(13,14) . E_{1} S$ has been the major urinary estrogenic metabolite. As Purdy et al. (2) showed, it is also the major plasma metabolite of estradiol. We had postulated that there was a large plasma compartment that slowly exchanged with plasma estrone and estradiol (3), and it seemed likely that this was $\mathrm{E}_{1} \mathrm{~S}$. This and the lack of information concerning origin, clearance rates, and metabolism of $\mathrm{E}_{1} \mathrm{~S}$ prompted the studies reported here.

The $M C R_{\mathbf{E}_{1} s}$ was obtained by fitting the data obtained after rapid injection of $\mathrm{E}_{1} \mathrm{~S}_{-}{ }^{3} \mathrm{H}$ to a straight line thereby assuming a one-compartment model. Frequent samples were not obtained during the first $\mathrm{hr}$ so that a rapid component of the disappearance curve would have been missed. In two studies, the $30 \mathrm{~min}$ sample suggested an early faster component but this could exert little effect on the calculation of the MCR since the total rate of removal of $\mathrm{E}_{1} \mathrm{~S}$ from plasma is so slow. The study in subject 6 directly compared the MCR obtained assuming distribution into a single compartment and that obtained during constant infusion when plasma concentrations of $\mathrm{E}_{1} \mathrm{~S}-{ }^{3} \mathrm{H}$ were at equilibrium. Since results obtained by the latter method are independent of the compartmental distribution of the isotope, the agreement between these data is validation of our measurement of $\mathrm{MCR}_{\mathrm{E}_{1}} \mathrm{~s}$. In the single study of the clearance of DHS, a one-compartment model also was adequate to explain the distribution of the steroid (15). The estimated $\mathrm{MCR}_{\mathrm{E}_{1} \mathrm{~s}}$ of 150 liter/day is in agreement with 
${ }^{3} \mathrm{H}$ Infusions

\begin{tabular}{|c|c|c|c|c|c|c|c|c|}
\hline \multicolumn{4}{|c|}{ Plasma tritium levels } & \multirow{2}{*}{$\begin{array}{l}\text { Equilibrium } \\
{ }^{2} \mathrm{H} \text { levels }\end{array}$} & \multirow{2}{*}{$\begin{array}{c}\text { CE2E1S } \\
\mathrm{E}_{1} \mathrm{~S}^{-3} \mathrm{H} / \mathrm{E}_{2^{-3}-3} \mathrm{H}\end{array}$} & \multirow[b]{2}{*}{$\mathrm{MCRE}_{2}$} & \multirow[b]{2}{*}{$\mathrm{MCRE}_{2}$} & \multirow[b]{2}{*}{${ }_{\rho} \mathrm{E}_{2} \mathrm{E}_{1} \mathrm{~S} *$} \\
\hline $3.0 \mathrm{hr}$ & $3.5 \mathrm{hr}$ & $5.0 \mathrm{hr}$ & $7.0 \mathrm{hr}$ & & & & & \\
\hline & \multicolumn{2}{|c|}{$c p m \times 10^{-3} /$ liter } & & $\mathrm{cpm} /$ liter $\times 10^{-3}$ & & liter/day & liter $/ d a y / m^{2}$ & \\
\hline $\begin{array}{l}111 \\
293\end{array}$ & $\begin{array}{l}108 \\
318\end{array}$ & & & $\begin{array}{r}110 \\
1210\end{array}$ & 11.0 & 1200 & 739 & 0.59 \\
\hline \multirow[t]{6}{*}{$\begin{array}{r}58 \\
108\end{array}$} & & $\begin{array}{c}68 \\
200\end{array}$ & $\begin{array}{c}81 \\
275\end{array}$ & $\begin{array}{l}74.5 \\
432\end{array}$ & 5.8 & 1230 & 832 & 0.81 \\
\hline & & & & $\begin{array}{l}138 \\
425\end{array}$ & 3.08 & 920 & 520 & 0.56 \\
\hline & & & & $\begin{array}{r}71.5 \\
157\end{array}$ & 2.19 & 1594 & 886 & 0.22 \\
\hline & & & & $\begin{array}{l}59.9 \\
815\end{array}$ & 13.6 & 1770 & 983 & 1.20 \\
\hline & & & & $\begin{array}{l}62.0 \\
414\end{array}$ & 6.68 & 2032 & 1129 & 0.52 \\
\hline & & & & & 【7.06 \} $&{ } &{ } &{0.65} \\
$\hline
\end{tabular}

data reported recently by Longcope (16) and confirms the early work of Twombly and Levitz (1) who showed that $E_{1} S$ is cleared from the blood slowly.

The plasma $\mathrm{MCR}_{\mathbf{E}_{1} \text { S }}$ of 150 liter/day is considerably higher than the plasma MCR of DHS (7 liter/day) (15), and of the blood MCR of DHS (16-30 liter/day) (17), testosterone sulfate (25 liter/day) (17), 17acetoxypregnenolone sulfate (37 liter/day) (18). A recent report gives values for testosterone sulfate MCR of 75-240 liter/day which are in the same range as our estimates of $\mathrm{MCR}_{\mathbf{E}_{1} \mathbf{S}}$ (19). However, the fractional pool turnover rate of $\mathrm{E}_{1} \mathrm{~S}$ of 3.3 pools/day is about the same as the fractional pool turnover rates of other steroid sulfates $(15,17-19)$. Thus, the higher $\mathrm{MCR}_{\mathrm{E}_{1} \mathrm{~s}}$ must be associated with a larger volume of distribution of $E_{1} S$, and in fact its volume of distribution of about 50 liters is higher than those of the other steroids (15, $17,18)$ which have lower MCR. Only pregnenolone sulfate had a higher MCR than $E_{1} S$ but it had a relatively small volume of distribution ( 7 liters) and a higher fractional turnover rate almost equal to that of some unconjugated steroids (18).

The volume of distribution of the steroid sulfate depends on the binding of the sulfates to plasma proteins, in particular to albumin. Binding to albumin in man has been demonstrated by Puche and Nes (20), Sandberg and Slaunwhite (21), and Plager (22). Puche and Nes, Plager, and Wang and Bulbrook (23) noted that all steroid sulfates tested competed for the same binding sites. However, the association constants were influenced by the nature of the steroid. The association constant of DHS with albumin has been reported as $0.6-2 \times 10^{5} \mathrm{liter} / \mathrm{mole}(20,22)$, whereas the $\mathrm{E}_{1} \mathrm{~S}$ binding constant was estimated at $2 \times 10^{4}$ liter/ mole (24). Although these binding affinities were not obtained in the same system, the association of lower affinity constants with higher volumes of distribution is apparent. It therefore seems probable that the clearance rates of the steroid sulfates vary inversely with the tightness of binding to albumin which in turn determines the volume of distribution.

Using the average $\mathrm{MCR}_{\mathrm{E}_{1} \mathrm{~s}}$ and mean $\mathrm{E}_{1} \mathrm{~S}$ plasma concentrations, we found that plasma production rates of $E_{1} S$ were similar to those of estrone and estradiol in men and women. Although we have not looked for possible variations of $E_{1} S$ concentrations throughout the day, it can be shown that they will not vary greatly because of the low fractional pool turnover rate $(\gamma)$. Thus, the $E_{1} S$ production rates need not be corrected for a mean plasma $\mathrm{E}_{1} \mathrm{~S}$ concentration, and should closely approximate the $24-\mathrm{hr}$ production rates of $\mathrm{E}_{1} \mathrm{~S}$.

Since sulfokinases are present in peripheral tissues as well as in the gonads and adrenal cortex, we could not know to what extent $E_{1} S$ was either secreted ${ }^{2}$ or

\footnotetext{
'The term "secretion" is used to indicate entry of the steroid into the plasma from the glands. The term "production" signifies the rate of entry of the steroid from all
} sources. 
produced from peripheral transformation of plasma precursors. We therefore calculated the contributions of plasma estrone and estradiol to the $E_{1} S$ production rate. To do this, we used our values for transfer factors, $\rho^{\mathbb{E}_{1} \mathbb{E}_{1} \mathrm{~s}}, \rho^{\mathbb{E}_{2} \mathbb{E}_{1} \mathbf{S}} ; \rho^{\mathbb{E}_{1} \mathrm{SE}_{1}}, \rho^{\mathbb{E}_{1} \mathrm{SE}_{2}}$ (Tables II-V) as well as the average transfer factors, $\rho^{\mathbf{E}_{1} \mathbf{E}_{2}}, \rho^{\mathbf{E}_{2} \mathrm{E}_{1}}(25,26)$. The following three equations give solutions for the net amount of steroid entering the plasma from all sources (shown by [] ) other than from conversion of the two other steroids :

$$
\begin{aligned}
{\left[E_{1}\right] } & =\mathrm{PR}_{\mathrm{E}_{1}}-\rho^{\mathrm{E}_{1} \mathrm{SE}_{1}}\left[\mathrm{E}_{1} \mathrm{~S}\right]-\rho^{\mathrm{E}_{2} \mathrm{E}_{1}}\left[\mathrm{E}_{2}\right], \\
{\left[\mathrm{E}_{2}\right] } & =\mathrm{PR}_{\mathrm{E}_{2}}-\rho^{\mathrm{E}_{1} \mathrm{SE}_{2}}\left[\mathrm{E}_{1} \mathrm{~S}\right]-\rho^{\mathrm{E}_{1} \mathrm{E}_{2}}\left[\mathrm{E}_{1}\right], \\
{\left[\mathrm{E}_{1} \mathrm{~S}\right] } & =\mathrm{PR}_{\mathrm{E}_{1} \mathrm{~S}}-\rho^{\mathrm{E}_{1} \mathrm{E}_{1} \mathrm{~S}}\left[\mathrm{E}_{1}\right]-\rho^{\mathrm{E}_{2} \mathrm{E}_{1} \mathrm{~S}}\left[\mathrm{E}_{2}\right] .
\end{aligned}
$$

Since the production rates $(P R)$ and transfer factors are known, the equations can be solved for the [ ] values. These values are not true secretion rates since they would include any steroid produced from other precursors. For example, $\left[\mathrm{E}_{1}\right]$ would include that estrone derived from plasma androstenedione and testosterone as well as that moiety that is secreted.

The derived data are given in Table VI. For each subgroup, $\left[\mathrm{E}_{1} \mathrm{~S}\right]$ was negative. This means that the production rate calculated to result from conversion of plasma estrone and estradiol is higher than that calculated by direct measurement of the $\mathrm{MCR}_{\mathrm{E}_{1} \mathrm{~s}}$ and plasma $E_{1} S$ concentration. Hence, there is no need to postulate glandular secretion of $E_{1} S$. The lack of correspondence of the data must be explained and serves to point out the many sources of discrepancies in all studies such as this.

The first and most important reason for lack of correspondence in calculations such as these is not really "error" but relates to the large range of normal average values for metabolic clearance rates and transfer factors that are used. Inspection of published data for metabolic clearance rates of $E_{1}$ and $E_{2}(3,25,26)$ reveals not only a large range of values for normals but also for groups of normals studied in the same laboratory $(25,26)$. This same large range of normal values

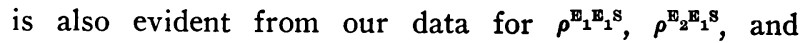
$M C R_{\mathrm{F}_{1} \mathrm{~s}}$. Since our study included only a small sample from a population with a large normal range, it is possible that our average values for $\rho^{\mathrm{E}_{1} \mathrm{E}_{1} \mathrm{~s}}, \rho^{\mathrm{E}_{2} \mathrm{~B}_{1} \mathrm{~s}}$ could be considerably higher than the true mean for the normal population. Agreement between the calculations would be possible only if all parameters were measured in the same normal subjects. Secondly, average values for estradiol concentrations in men reported by us previously (5) and used for our calculations of $\mathrm{E}_{2}$ production rates are somewhat higher than more recent values of $20-25 \mathrm{pg} / \mathrm{ml}$ reported by other laboratories (9-11). The errors in measurement of low estrogen concentrations by radioligand assays tend to cause high values which would result in overestimation of production rates. The consistent finding that estrogen production rates, calculated from dilution of labeled estrogen into urinary metabolites, are smaller than those calculated from the MCR and plasma concentration is further evidence that the latter method overestimates the production rate. Next, the known diurnal variations in plasma estrone concentration $(27,28)$ and possibly of estradiol, mean that production rates obtained using morning plasma estrogen concentrations will systematically overestimate the $24 \mathrm{hr}$ estrogen production rate of these unconjugated estrogens. Finally, since plasma estradiol and estrone have plasma turnovers of about 50 pools/day and $E_{1} S$ turnover rate is 3.3 pools/day, plasma concentrations of $E_{1} S$ will lag behind plasma estrone and estradiol by 6-12 $\mathrm{hr}$. Therefore, it will be difficult to arrive at correct sampling times to estimate the contributions of estrone and estradiol to $E_{1} S$ production rates.

Since most of the errors discussed will cause overestimation of estrone and estradiol blood production rates, the amount of $E_{1} S$ calculated to arise from these sources will also be overestimated. Nevertheless, all $E_{1} S$ found in plasma can be accounted for merely by using mean values \pm standard deviations for production rates and $\rho$ used in the calculations. Hence, it is untenable

\begin{tabular}{|c|c|c|c|c|c|c|c|}
\hline & {$\left[\mathrm{E}_{1}\right]^{*}$} & $\rho \mathbb{E}_{1} E_{1} S\left[E_{1}\right]$ & {$\left[\mathrm{E}_{2}\right]$} & $\rho \mathrm{E}_{2} \mathrm{E}_{1} \mathrm{~S}\left[\mathrm{E}_{2}\right]$ & {$\left[\mathrm{E}_{1} \mathrm{~S}\right]$} & $\begin{array}{c}P R E_{1} S \\
\text { (from } E_{1} \text { and } E_{2} \text { ) }\end{array}$ & $\begin{array}{c}\mathrm{PR} \mathrm{ER}_{1} \mathrm{~S} \\
(\mathrm{MCR} \times \mathrm{i})\end{array}$ \\
\hline Men & $153 \ddagger$ & 82.6 & 74.5 & 48.5 & -54 & 131 & 77 \\
\hline Women & & & & & & & \\
\hline Follicular phase & 137 & 74 & 157 & 102 & -81 & 176 & 95 \\
\hline Women & & & & & & & \\
\hline Luteal phase & 175 & 94.5 & 279 & 181 & -94 & 275 & 182 \\
\hline
\end{tabular}

TABLE VI

Origin of Estrone Sulfate

* []$=$ the amount of steroid entering the plasma from all sources other than the two other steroids.

$\ddagger$ All values are micrograms per day, expressed as $\mathrm{E}_{1} \mathrm{~S}$. 
to suggest (29) that $E_{1} S$ may be secreted in amounts sufficient to make it a significant precursor of plasma estrone.

The transfer factor, $\rho^{\mathbb{E}_{1} \mathrm{SE}_{1}}$ of 0.21 was derived from the conversion ratios obtained from the short infusions of $\mathrm{E}_{1} \mathrm{~S}$ during which plasma levels of $\mathrm{E}_{1} \mathrm{~S}-{ }^{3} \mathrm{H}, \mathrm{E}_{1}-{ }^{3} \mathrm{H}$, and $\mathrm{E}_{2}-{ }^{3} \mathrm{H}$ were increasing in four of the five studies. However, $\rho^{\mathrm{E}_{1} \mathrm{SE}_{1}}$ and $\rho^{\mathrm{E}_{1} \mathbf{S E}_{2}}$ appeared to be at equilibrium. The $\rho^{\mathrm{E}_{1} \mathrm{SE}_{1}}$ of 0.21 agrees closely to that of 0.15 reported recently by Longcope (16). The transfer factor, $\rho^{\mathbf{E}_{1} \mathbf{S E}_{2}}$ was only $10 \%$ of that for estrone (Table IV). Since $\rho^{\mathrm{E}_{1} \mathbf{E}_{2}}$ is also about $10 \%(25,26)$, it is probable that $E_{1} \mathrm{~S}$ reaches the plasma estradiol compartment via plasma estrone. Although the mass of estrone sulfate available for exchange with $\mathrm{E}_{1}$ is large, about 25$50 \mu \mathrm{g}$ (plasma concentration $\times$ volume of distribution), only 5-10 $\mu \mathrm{g}$ could enter the plasma volume daily as estrone. This is a small fraction of estimated estrone production rates of $40-200 \mu \mathrm{g} /$ day in men and women.

Although $\rho^{\mathbb{E}_{1} \mathrm{SE}_{1}}$ and $\rho^{\mathrm{E}_{1} \mathrm{SE}_{2}}$ were apparently at equilibrium, computer simulations of these studies ${ }^{3}$ using the SAAM program of Berman and Weiss (12) have shown that these conversion ratios cannot be at equilibrium and that the true conversion ratio may be greater by about $15 \%$. Short sampling times and variability in the determinations mask this trend. For the purposes of understanding these facets of estrone sulfate metabolism, the values used in our calculations are sufficiently accurate although they are not equilibrium values.

In contrast to the low biologic potency of orally administered estrone and estradiol, $\mathrm{E}_{1} \mathrm{~S}$ is an active oral estrogen. Our data confirm that it is rapidly absorbed from the gut and reaches the peripheral circulation without significant metabolism by the liver. Since 0.5 $\mathrm{mg}$ of estrone sulfate is an adequate replacement dose for many postmenapausal women, we have calculated that the plasma estrone production rate resulting from this dose is $70 \mu \mathrm{g} /$ day $(0.5 \times 0.7 \times 0.2)$. Similarly, the resultant estradiol production rate would be $7 \mu \mathrm{g}$ / day. The minimal estrogen production rates that cause either vaginal cornification or endometrial hyperplasia are unknown but Grodin and $\mathrm{McDonald}^{5}$ found that an estrone production rate greater than $40 \mu \mathrm{g} /$ day (by urinary isotope dilution) induced endometrial hyperplasia in women. The estrone production rate of normal postmenapausal women calculated from plasma concentrations and metabolic clearance rates is about $40 \mu \mathrm{g} /$ day (30) and there is little biologic estrogenic effect at these

\footnotetext{
${ }^{3}$ Ruder, H. J., L. Loriaux, M. B. Lipsett, and M. Berman. Manuscript in preparation.

${ }^{4}$ Dose of $\mathrm{E}_{1} \mathrm{~S}$ is $0.5 \mathrm{mg} /$ day; the transfer constant, $\rho^{\mathrm{E}_{1} \mathrm{sE}_{1}}$ is 0.2 and only $70 \%$ of $\mathrm{E}_{1} \mathrm{~S}$ is estrone by weight.

${ }^{5}$ Grodin and McDonald. Personal communication.
}

levels. Thus it may be that the conversion of orally administered estrone sulfate to plasma estrone and estradiol is sufficient to account for its biologic effect. In this regard, it is of interest that Gurpide, Stolee, and Tseng (31) reported that human endomentrium rapidly metabolized estrone sulfate to estrone and estradiol.

In summary: (a) $\mathrm{E}_{1} \mathrm{~S}$ is a major circulating plasma estrogen and has a long plasma half-life; $(b)$ the large contributions of estrone and estradiol to plasma $E_{1} S$ are more than sufficient to account for all the circulating plasma $\mathrm{E}_{1} \mathrm{~S} ;(c)$ orally administered $\mathrm{E}_{1} \mathrm{~S}$ is metabolized to plasma estrone and estradiol to the same extent as i.v. administered $\mathrm{E}_{1} \mathrm{~S}$.

\section{APPENDIX}

Because of the slow fractional turnover rate of $E_{1} S$, measurement of $\rho^{E_{1} E_{1} S}$ and $\rho^{E_{2} E_{1} S}$ at equilibrium values of $E_{1}, E_{2}$, and $\mathrm{E}_{1} \mathrm{~S}$ was impossible unless infusions were carried out for longer than $24 \mathrm{hr}$. Since the dissappearance of $\mathrm{E}_{1} \mathrm{~S}$ from plasma can be adequately described by a single exponential, this same single exponential describes the appearance of $E_{1} S$ in plasma during an infusion of $\mathrm{E}_{1}-{ }^{3} \mathrm{H}$ or $\mathrm{E}_{2}-{ }^{3} \mathrm{H}$. When plasma levels of $\mathrm{E}_{1}-{ }^{3} \mathrm{H}$ and $\mathrm{E}_{2}-{ }^{3} \mathrm{H}$ are at equilibrium, a constant amount of $\mathrm{E}_{1}-{ }^{3} \mathrm{H}$ or $\mathrm{E}_{2}-{ }^{3} \mathrm{H}$ is being metabolized to $\mathrm{E}_{1} \mathrm{~S}$. Thus when estrone or estradiol is infused at rates such that their plasma levels reach equilibrium values, $E_{1} S$ enters the plasma at a rate equal to the $\rho^{E_{1} E_{1} S}$ or $\rho^{E_{2} E_{1} S} \times$ the infusion rate of $\mathrm{E}_{1}-{ }^{3} \mathrm{H}$ or $\mathrm{E}_{2}-{ }^{3} \mathrm{H}$. We were therefore able to estimate $C^{E_{1} E_{1} s}, C^{E_{2} E_{1} s}$ during short infusions of either $\mathrm{E}_{1}-{ }^{3} \mathrm{H}$ or $\mathrm{E}_{2}-{ }^{3} \mathrm{H}$ by making the following assumptions:

(a) The bolus given before the $\mathrm{E}_{1}$ or $\mathrm{E}_{2}$ infusions adequately sets the plasma $\mathrm{E}_{1}-{ }^{3} \mathrm{H}$ or $\mathrm{E}_{2}-{ }^{3} \mathrm{H}$ at an equilibrium level that is then maintained by the constant $\mathrm{E}_{1}-{ }^{3} \mathrm{H}$ or $\mathrm{E}_{2}-{ }^{3} \mathrm{H}$ infusions. (b) A constant amount of $\mathrm{E}_{1}-{ }^{3} \mathrm{H}$ or $\mathrm{E}_{2}-{ }^{3} \mathrm{H}$ is being metabolized to $\mathrm{E}_{1} \mathrm{~S}-{ }^{3} \mathrm{H}$ from the time 0 when the bolus is given and hence a constant amount of $\mathrm{E}_{1} \mathrm{~S}-{ }^{3} \mathrm{H}$ is entering the plasma $E_{1} S$ pool during the entire time of the short $E_{1}$ or $E_{2}$ infusion. To verify these assumptions, we performed computer simulations of typical $\mathrm{E}_{1}-{ }^{3} \mathrm{H}$ or $\mathrm{E}_{2}-{ }^{3} \mathrm{H}$ infusions utilizing the computer model program of Berman and Weiss (12). We were able to show that the dose of $E_{1}-{ }^{3} \mathrm{H}$ or $\mathrm{E}_{2}-{ }^{3} \mathrm{H}$ given as a bolus to begin the short infusions adequately set the plasma level of $\mathrm{E}_{1}-{ }^{3} \mathrm{H}$ or $\mathrm{E}_{2}-{ }^{3} \mathrm{H}$ at near equilibrium levels; and that in addition, a constant amount of $E_{1} S-{ }^{3} \mathrm{H}$ is entering the plasma $E_{1} S$ pool from the time of the bolus at time 0 .

Thus, the instantaneous change in $\mathrm{E}_{1} \mathrm{~S}-{ }^{3} \mathrm{H}$ is described by the following,

$$
\frac{\mathrm{dE}_{1} \mathrm{~S}_{\mathrm{t}_{\mathbf{x}}}}{\mathrm{dt}}=\mathrm{k}_{1} \mathrm{E}_{1 \mathrm{tx}}-\gamma \mathrm{E}_{1} \mathrm{~S}_{\mathrm{tx}_{\mathbf{x}}}
$$

where $E_{1} S_{t_{x}}$ is the instantaneous level of $E_{1} S-{ }^{3} \mathrm{H}$ at time $t_{x}$; $E_{1}$ is the instantaneous level of $E_{1}-{ }^{3} \mathrm{H}$ at time $t_{x} ; k_{1}$ is the fractional turnover of $\mathrm{E}_{1}-{ }^{3} \mathrm{H}$ to $\mathrm{E}_{1} \mathrm{~S}-{ }^{3} \mathrm{H}$; and $\gamma$ is the total rate of removal of $\mathrm{E}_{1} \mathrm{~S}-{ }^{3} \mathrm{H}$ as given in Table I. Integrating and solving for $E_{1} S_{t_{x}}$ yields,

$$
\mathrm{E}_{1} \mathrm{~S}_{\mathrm{tx}_{\mathbf{x}}}=\frac{\mathrm{k}_{1} \mathrm{E}_{1 \mathrm{t}_{\mathbf{x}}}}{\gamma}\left(1-e^{-\gamma T_{\mathbf{x}}}\right)
$$

where $e$ is natural logarithm; $\mathrm{T}_{\mathbf{x}}$ is time after beginning the studies. By definition, however $C^{E_{1} E_{1} S}=E_{1} S-{ }^{3} \mathrm{H} / E_{1}-{ }^{3} \mathrm{H}$ 
when both are equilibrium values. And in fact, $\mathrm{E}_{1 \mathrm{tx}_{\mathrm{x}}}-{ }^{3} \mathrm{H}$ is at equilibrium from time 0 as explained above and will be written $\mathrm{E}_{1}-{ }^{3} \mathrm{H}$. Hence, $\mathrm{E}_{1 \mathrm{tz}_{\mathrm{z}}}-{ }^{3} \mathrm{H}=\mathrm{E}_{1}-{ }^{3} \mathrm{H}$. At time $\mathrm{T}_{\mathrm{x}}=\infty, \mathrm{E}_{1} \mathrm{~S}$ is also at equilibrium by defintion and $e^{-\gamma \mathbf{T}_{\mathbf{x}}}=0$ and yields:

$$
\mathrm{E}_{1} \mathrm{~S}_{\infty}=\frac{\mathrm{k}_{1} \mathrm{E}_{1}}{\gamma}(1-0) \text {. }
$$

Rearranging yields:

$$
\frac{\mathrm{E}_{1} \mathrm{~S}}{\mathrm{E}_{1}}=\frac{\mathrm{k}_{1}}{\gamma} .
$$

Since $C^{E_{1} E_{1} S}=E_{1} S-{ }^{3} \mathrm{H} / E_{1}-{ }^{3} H ; C^{E_{1} E_{1} S}=k_{1} / \gamma$. Thus,

$$
\mathrm{E}_{1} \mathrm{~S}_{\mathrm{tx}_{\mathrm{x}}}-{ }^{3} \mathrm{H}=\mathrm{C}^{\mathrm{E}_{1} \mathrm{E}_{1} \mathrm{~S}} \cdot\left(\mathrm{E}_{1}-{ }^{3} \mathrm{H}\right)\left(1-e^{-\gamma \mathrm{T}_{\mathbf{x}}}\right) .
$$

And rearranging :

$$
C^{E_{1} E_{1} S}=\frac{E_{1} S_{t_{x}}-{ }^{3} H}{\left(E_{1}-{ }^{3} H\right)\left(1-e^{-\gamma T_{x}}\right)}
$$

The same formula holds for $\mathrm{CE}_{2} \mathrm{E}_{1} \mathrm{~S}$ substituting appropriate values for $\mathrm{E}_{2}$ and $\gamma$. All conversion ratios shown in Tables IV and $\mathrm{V}$ were calculated using this formula and, where possible, the actual measured value for $\gamma$. Otherwise, average values for $\gamma$ were used from Table I. Since each infusion had at least three plasma samples at different time points, conversion ratios were calculated at each time point during a single infusion and averaged, yielding the values shown in Tables IV and V. Validity of these calculations was confirmed by using data from subjects 7 and 8 in whom we had estimates of all MCR and plasma concentrations for computer simulation using the SAAM program of Berman and Weiss (12). There was close agreement between conversion ratios predicted by the computer program and the conversion ratios calculated by the above formula.

\section{ACKNOWLEDGMENTS}

The assistance of Dr. Monas Berman in teaching the authors the use of the SAAM computer program and of Dr. David Rodbard for his aid in the derivation of the mathematical formulas is gratefully acknowledged.

\section{REFERENCES}

1. Twombly, G. H., and M. Levitz. 1960. Metabolism of estrone-C ${ }^{14}-16$ sulfate in women. Amer. J. Obstet. Gynecol. $80: 889$.

2. Purdy, R. H., L. L. Engel, and J. L. Oncley. 1961. The characterization of estrone sulfate from human plasma. J. Biol. Chem. 236: 1043.

3. Hembree, W. C., C. W. Bardin, and M. B. Lipsett. 1969. A study of estrogen metabolic clearance rates and transfer rates. J. Clin. Invest. 48: 1809.

4. Mumma, R. O., C. P. Hoiberg, and W. W. Weber. 1969. Preparation of sulfate esters. The synthesis of steroid sulfates by a dicyclohexyl-carbodiimide medicated sulfation. Steroids. 14: 67.

5. Loriaux, D. L., H. J. Ruder, and M. B. Lipsett. 1971. The measurement of estrone sulfate in plasma. Steroids. 18: 463

6. Ruder, H. J., P. Corvol, J. A. Mahoudeau, G. T. Ross, and M. B. Lipsett. 1971. Effects of induced hyperthyroidism on steroid metabolism in men. J. Clin. Endocrinol. Metab. 33: 382.
7. Bardin, C. W., and M. B. Lipsett. 1967. Testosterone and androstenedione blood production rates in normal women with idiopathic hirsutism or polycystic ovaries. J. Clin. Invest. 46: 891.

8. Horton, R., and J. F. Tait. 1966. Androstenedione production and interconversion rates measured in peripheral blood and studies on the possible site of its conversion to testosterone. J. Clin. Invest. 45: 301.

9. Baird, D. T. 1968. A method for the measurement of estrone and estradiol-17 in peripheral human blood and other biological fluids using ${ }^{35} \mathrm{~S}$ pipsyl chloride. J. Clin. Endocrinol. Metab. 28: 244.

10. Korenman, S. G., L. E. Perrin, and T. P. McCallum. 1969. A radio-ligand binding assay system for estradiol measurement in human plasma. J. Clin. Endocrinol. Metab. 29: 879 .

11. Nagai, N., and C. Longcope. 1971. Estradiol-17 and estrone: studies on their binding to rabbit uterine cytosol and their concentration in plasma. Steroids. 17: 631.

12. Berman, M., and M. F. Weiss. 1967. Users manual for SAAM. U. S. Government Printing Office, Washington, D. C. Publication No. 1703.

13. Howard, G. M., H. Robinson, F. H. Schmidt, J. R. Mccord, and J. R. Preedy. 1969. Evidence for a two-pool system governing the excretion of radioactive urinary estrogen conjugates during the first eight hours following the administration of estrone- $6,7-{ }^{3} \mathrm{H}$ to male subjects. Probable role of the enterohepatic circulation. $J$. Clin. Endocrinol. Metab. 29: 1618.

14. Hobkirk, R., M. Nilsen, and P. R. Blahey. 1969. Conjugation of urinary phenolic steroids in the nonpregnant human female with particular reference to estrone sulfate. J. Clin. Endocrinol. Metab. 29: 328.

15. Sandberg, E., E. Gurpide, and S. Lieberman. 1964. Quantitative studies on the metabolism of dehydroisoandrosterone sulfate. Biochemistry. 3: 1256.

16. Longcope, C. 1972. The metabolism of estrone sulfate in normal males. J. Clin. Endocrinol. Metab. 34: 113.

17. Wang, D. Y., R. D. Bulbrook, A. Sneddon, and T. Hamilton. 1967. The metabolic clearance rates of dehydroepiandrosterone, testosterone and their sulfate esters in man, rat and rabbit. J. Endocrinol. 38: 307.

18. Wang, D. Y., D. R. Bulbrook, F. Ellis, and M. M. Coombs. 1967. Metabolic clearance rates of pregnenolone, 17-acetoxypregnenolone and their sulphate esters in man and in rabbit. J. Endocrinol. 39: 395.

19. Saez, J. M., J. Bertrand, and C. J. Migeon. 1971. Metabolic clearance rate, urinary and plasma production rates of testosterone sulfate in man. Steroids. 17: 435.

20. Puche, R. C., and W. R. Nes. 1962. Binding of dehydroepiandrosterone sulfate to serum albumin. Endocrinology. 70: 857.

21. Sandberg, A. A., and W. R. Slaunwhite. 1957. The binding of steroids and steroid conjugates to human plasma proteins. Recent Progr. Hormone Res. 13: 209.

22. Plager, J. E. 1965. The binding of androsterone sulfate, etiocholanolone sulfate, and dehydroisoandrosterone sulfate by human plasma protein. J. Clin. Invest. 44: 1234.

23. Wang, D. Y., and R. D. Bulbrook. 1967. Binding of the sulfate esters of dehydroepiandrosterone, testosterone, 17 -acetoxypregnenolone and pregnenolone in the plasma of man, rabbit and rat. J. Endocrinol. 39: 405.

24. Sandberg, A. A., H. Rosenthal, S. L. Schneider, and W. R. Slaunwhite. 1966. Steroid interactions and their 
role in the transport of steroids. In Steroid Dynamics. G. Pincus, T. Nokao, and J. F. Tait, editors. Academic Press, Inc., New York. 1-61.

25. Longcope, C., D. S. Layne, and J. F. Tait. 1968. Metabolic clearance rates and interconversions of estrone and 17-estradiol in normal males and females. J. Clin. Invest. 47: 93.

26. Longcope, C., and J. F. Tait. 1971. Validity of metabolic clearance and interconversion rates of estrone and 17estradiol in normal adults. J. Clin. Endocrinol. Metab. 32: 481.

27. Baird, D. T., and A. Guevara. 1969. Concentration of unconjugated estrone and estradiol in peripheral plasma in nonpregnant women throughout the menstrual cycle, castrate and postmenopausal women and in men. J. Clin. Endocrinol. Metab. 29: 149.

28. Tulchinsky, D., and S. G. Korenman. 1970. A radioligand assay for plasma estrone; normal values and variation during the menstrual cycle. J. Clin. Endocrinol. Metab. 31: 76 .

29. Baird, D., R. Horton, C. Longcope, and J. F. Tait. 1968. Steroid prehormones. Perspect. Biol. Med. 11: 384.

30. Longcope, C. 1971. Metabolic clearance and blood production rates of estrogens in postmenopausal women. Amer. J. Obstet. Gynecol. 111: 778.

31. Gurpide, E., A. Stolee, and L. Tseng. 1971. Quantitative studies of tissue uptake and disposition of hormones. Acta Endocrinol. Suppl. 153. 